\title{
Synthesis and Characterization of Spinel $\mathrm{Li}_{4} \mathrm{Ti}_{5} \mathrm{O}_{12}$ Anode Material by CTAB Assisted Sol-Gel Method
}

\author{
F. Kiliç Dokan, H. Şahan, B. Özdemir, N. Özdemir And Ş. Patat \\ Department of Chemistry, Faculty of Science, University of Erciyes, Kayseri, 38039, Turkey
}

\begin{abstract}
Recently, there has been considerable interest in $\mathrm{Li}_{4} \mathrm{Ti}_{5} \mathrm{O}_{12}$ as a potential anode for use in lithium ion batteries. It has many advantages compared to the currently used graphite. It has a good reversibility but no structural change. The material has a theoretical specific capacity of $175 \mathrm{mAh} \mathrm{g}^{-1} \cdot \mathrm{Li}_{4} \mathrm{Ti}_{5} \mathrm{O}_{12}$ powders are usually synthesized by a solid-state reaction of lithium and titanium salts. This method was generally preferred because the synthesis procedures are simple. But there are some disadvantages of solid-state methods such as larger particle size of the products, inhomogeneous distribution, lack of stoichiometry control, etc. These disadvantages can be overcome by sol-gel method. Using surfactant in sol-gel method is easy control on crystal growth and size of the desired products.
\end{abstract}

DOI: $10.12693 /$ APhysPolA.125.648

PACS: 88.80.ff

\section{Introduction}

The lithium-ion rechargeable batteries have been widely used in portable electronic devices such as laptop computers, mobile phones, and camcorders. It is also very promising to use these batteries as power sources for electric vehicles. The spinel $\mathrm{Li}_{4} \mathrm{Ti}_{5} \mathrm{O}_{12}$ has been demonstrated as good candidate as anode for solid-state lithium ion batteries [1-4]. It has a good Li-ion intercalation and de-intercalation reversibility and exhibits no structural change during charge-discharge cycling. This active material has a main discharge platform close to $1.55 \mathrm{~V}$ versus $\mathrm{Li}^{+} / \mathrm{Li}$, which is very promising for electrodes in a large number of battery applications.

It is believed that particle size and morphology have an influence on the cell performance of electrode materials. In particular, a decrease in mean particle size results in an increase in cyclability and rate capability of electrode materials because smaller particles are more flexible for lithium insertion/deinsertion than larger particles. In most studies, $\mathrm{Li}_{4} \mathrm{Ti}_{5} \mathrm{O}_{12}$ has been synthesized using solid-state reaction that involves the mechanical mixing of oxides and/or carbonates, firing at higher temperature (about $800-1100^{\circ} \mathrm{C}$ ), and then further grinding. These synthetic conditions (for example, sintering time and temperature), which require long-range diffusion of the reactants, may result in non-homogeneity, irregular morphology, large particle sizes, broad particle size distribution, and poor control of stoichiometry. In order to achieve good efficiency of Li utilization at high current rates and reliability of lithium secondary batteries, a sol-gel method has been introduced [5-7].

\section{Experimental}

A stoichiometric amount of titanium isopropoxide and lithium acetate $(\mathrm{Li} / \mathrm{Ti}=4.25: 5)$ were mixed in $75 \mathrm{~mL}$ of ethanol solvent and stirred at room temperature. The saturated solution of cetyltrimethylammonium bromide (CTAB) was prepared with the deionized water under continuous stirring for $2 \mathrm{~h}$, after that this solution was added to titanium isopropoxide and lithium acetate solution. The transparent solution turned white after stirring it for $20 \mathrm{~min}$. The temperature of the solution was raised to $90^{\circ} \mathrm{C}$ and stirred continuously to form the gel. The gel was aged at $100^{\circ} \mathrm{C}$ for $24 \mathrm{~h}$ in air and the precursor was decomposed at $400{ }^{\circ} \mathrm{C}$ for $4 \mathrm{~h}$ followed by calcination at $800^{\circ} \mathrm{C}$ for $12 \mathrm{~h}$ in air. For comparison purpose, we have also synthesized the sample without CTAB under identical reaction conditions.

Phase identification was carried out by X-ray powder diffraction (XRD, Bruker D8 Advance). The diffraction patterns were recorded in the $10-90^{\circ}$ range. The morphology and microstructure of samples were observed by scanning electron microscopy (LEO 440). The electrochemical performance was investigated by galvanostatic charge/discharge experiments. Two-electrode teflon cell was used to evaluate the electrochemical properties of $\mathrm{Li}_{4} \mathrm{Ti}_{5} \mathrm{O}_{12}$ anode material by CTAB assisted solgel method electrodes. The electrochemical cells consisted of Li-metal sheet as a counter electrode and $1 \mathrm{M} \mathrm{LiPF} 6$ in ethylene carbonate/diethyl carbonate (EC/DEC, 1:1 vol.\%) as a liquid electrolyte. Cell construction and sealing were carried out in an argon filled glove box. Galvanostatic cycling was performed between $1 \mathrm{~V}$ and $2.8 \mathrm{~V}$ with $1 \mathrm{C}$ on an MLab Multi Channel battery tester.

\section{Results and discussion}

The XRD patterns of all powders are presented in Fig. 1. The diffraction peaks conform to spinel $\mathrm{Li}_{4} \mathrm{Ti}_{5} \mathrm{O}_{12}$ structure (JCPDS file no. 49-0207) without obvious impurity phase. All the sharp diffraction peaks were indexed on the basis of a cubic spinel structure.

Crystal size of compounds.

TABLE

\begin{tabular}{l|c}
\hline \hline \multicolumn{1}{c|}{ Compounds } & Crystal size [nm] \\
\hline $\mathrm{Li}_{4.25} \mathrm{Ti}_{5} \mathrm{O}_{12}$ (sol-gel method) & 126 \\
$\mathrm{Li}_{4.25} \mathrm{Ti}_{5} \mathrm{O}_{12}$ (synthesized with CTAB & 110 \\
assisted sol-gel method) &
\end{tabular}




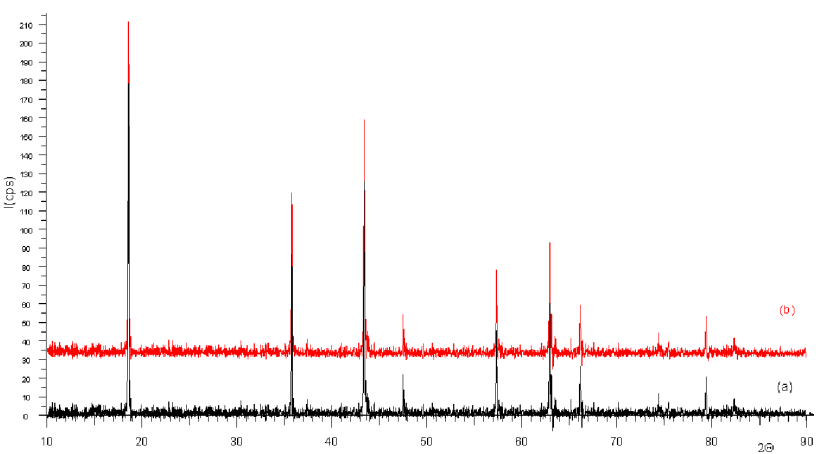

Fig. 1. XRD pattern of (a) $\mathrm{Li}_{4.25} \mathrm{Ti}_{5} \mathrm{O}_{12}$ (synthesized with sol-gel method) and (b) $\mathrm{Li}_{4.25} \mathrm{Ti}_{5} \mathrm{O}_{12}$ (synthesized with CTAB assisted sol-gel method).
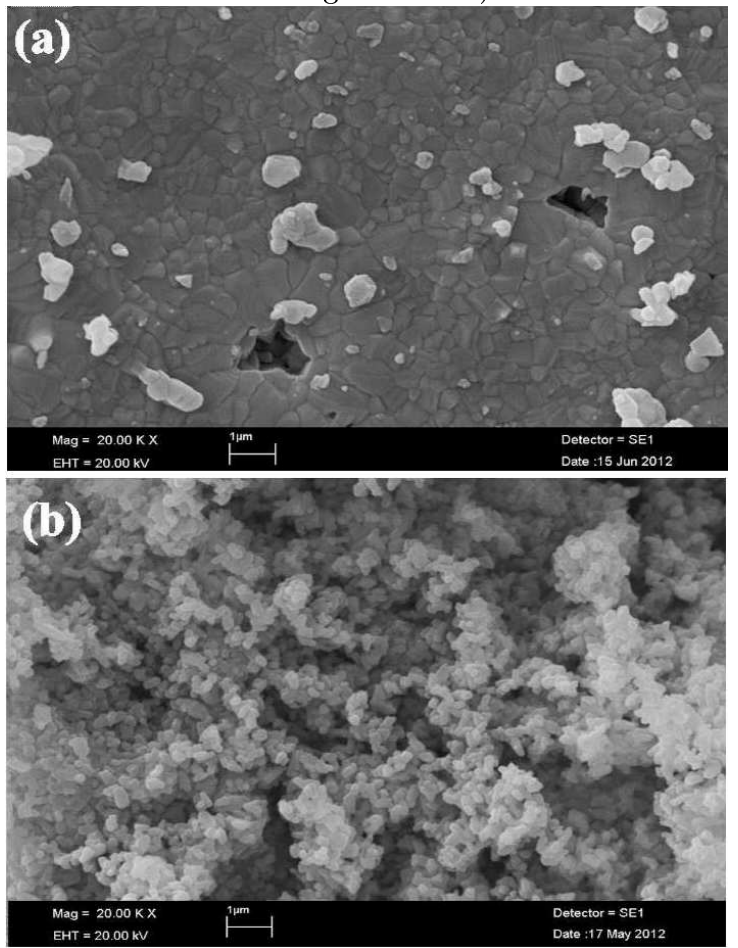

Fig. 2. SEM images of (a) $\mathrm{Li}_{4.25} \mathrm{Ti}_{5} \mathrm{O}_{12}$ (synthesized with sol-gel method), (b) $\mathrm{Li}_{4.25} \mathrm{Ti}_{5} \mathrm{O}_{12}$ (synthesized with CTAB assisted sol-gel method).
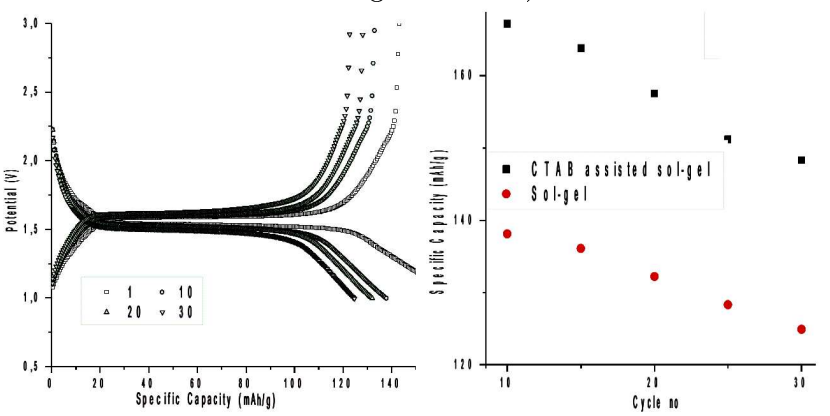

Fig. 3. (left) Charge discharge curves of $\mathrm{Li}_{4} \mathrm{Ti}_{5} \mathrm{O}_{12}$ synthesized with sol-gel method; (right) Cycling performances of $\mathrm{Li}_{4} \mathrm{Ti}_{5} \mathrm{O}_{12}$ synthesized with sol-gel method and CTAB assisted sol-gel method.
The crystallite sizes of samples are calculated from the Scherrer formula, $D=0.94 \lambda / \beta_{1 / 2} \cos (\Theta)$ and given in Table, where $D$ is the crystallite size $[\mathrm{mm}], \lambda$ is the wavelength of the X-ray radiation $(0.15418 \mathrm{~nm}$ for $\mathrm{Cu}$ $\left.\mathrm{K}_{\alpha}\right), \Theta$ is the Bragg angle and $\beta_{1 / 2}$ is the full width half maximum (FWHM) of the diffraction peak measured at $2 \Theta$ in radians.

Figure 2 shows the morphology of sol-gel method and synthesized with CTAB assisted sol-gel method. The morphological analysis shows that CTAB plays a significant role in the preparation of nanosized $\mathrm{Li}_{4} \mathrm{Ti}_{5} \mathrm{O}_{12}$. The CTAB mixed in an alkoxide solution modifies the microstructure of the gels, allowing the formation of oxides with controlled particle size and homogeneous particle size distribution of pure spinel-phase $\mathrm{Li}_{4} \mathrm{Ti}_{5} \mathrm{O}_{12}$. The average particle size was about $150-200 \mathrm{~nm}$.

Figure 3(left) shows the charge-discharge curves between $1 \mathrm{~V}$ and $2.8 \mathrm{~V}$ for $\mathrm{Li}_{4} \mathrm{Ti}_{5} \mathrm{O}_{12}$ synthesized with sol gel method. It can be seen that the charge-discharge curves shows very flat voltage plateau at around $1.56 \mathrm{~V}$ versus $\mathrm{Li}^{+} / \mathrm{Li}$, which is characteristic of spinel-phase $\mathrm{Li}_{4} \mathrm{Ti}_{5} \mathrm{O}_{12}$. Figure 3(right) shows the cycling performances of $\mathrm{Li}_{4} \mathrm{Ti}_{5} \mathrm{O}_{12}$ synthesized with sol-gel method and CTAB assisted sol-gel method.

\section{Conclusions}

In summary, the study reports the preparation of nanosized $\mathrm{Li}_{4} \mathrm{Ti}_{5} \mathrm{O}_{12}$ powder with narrow particle-size distribution by CTAB-assisted sol-gel method. The presence of CTAB shows better electrochemical performance than in the sample prepared by normal sol-gel method. The formation of pure spinel-phase $\mathrm{Li}_{4} \mathrm{Ti}_{5} \mathrm{O}_{12}$ is established by powder X-ray diffraction. The discharge capacity value of $155 \mathrm{mAh} \mathrm{g}^{-1}$ is achieved after 30 cycles for the sample prepared by CTAB-assisted sol-gel method while the sample prepared by normal sol-gel method could sustain only $110 \mathrm{mAh} \mathrm{g}^{-1}$.

\section{Acknowledgments}

This study was financially supported by the Erciyes University Research Fund project number FBD-10-3314.

\section{References}

[1] K.M. Colbow, J.R. Dahn, R.R. Haering, J. Power Sources 26, 397 (1989).

[2] K. Zaghib, M. Armand, M. Gauthier, J. Electrochem. Soc. 145, 3135 (1998).

[3] T. Ohzuku, Y. Iwakoshi, K. Sawai, J. Electrochem. Soc. 140, 2490 (1993).

[4] M. Nishisawa, R. Hashitani, T. Itoh, T. Matsue, I. Uchida, Electrochem. Solid State Lett. 1, 10 (1998).

[5] K. Zaghib, M. Simoneau, M. Armand, M. Gauthier, J. Power Sources 81-82, 300 (1999).

[6] M.M. Thackeray, P.J. Johnson, L.A. De Picciott, Mater. Res. Bull. 19, 179 (1984).

[7] E. Ferg, R.J. Gummow, A. De Kock, M.M. Thackeray, J. Electrochem. Soc. 141, L147 (1994). 